\title{
Sintesis Nanoselulosa dari Limbah Hasil Pertanian dengan Menggunakan Variasi Konsentrasi Asam
}

\section{Synthesis of Nanoselulosa from Agricultural Waste Using Variation Acid Concentration}

\author{
Kurnia Rimadhanti Ningtyas ${ }^{* 1}$, M. Muslihudin ${ }^{2}$, Ira Novita Sari ${ }^{3}$ \\ ${ }^{1}$ Program Studi Pengembangan Produk Agroindustri/Politeknik Negeri Lampung \\ 2,3 Program Studi Teknologi Pangan/ Politeknik Negeri Lampung \\ *E-mail : ningtyas@polinela.ac.id
}

\begin{abstract}
Agricultural waste is a huge source of fiber. There are many agricultural waste products in Lampung Province including rice straw and corn. The utilization of agricultural waste is one solution to get cellulose-producing materials. Nanocellulose is one of the uses of cellulose which is very beneficial for life. Nanocellulose can be divided into 3 main types namely nano crystal cellulose, nanofibril cellulose, and bacterial nanocellulose. Nanocellulose has a diameter of 1-100 $\mathrm{nm}$ and a length of 500-2000 $\mathrm{nm}$. Several techniques were developed to extract nanocellulose from cellulose including acid hydrolysis, enzymatic hydrolysis, and mechanical processes. The use of each extraction method is possible to produce different types and properties of nanocellulose. This research aims to synthesize nanocellulose from agricultural waste with various concentrations of acid to produce cellulose with the best nano size ranging from $1-100 \mathrm{~nm}$. H2SO4 concentration variations used are 45\%, 55\%, and $65 \%$. From this study produced cellulose powders with varying nano sizes. The size of nanocellulose produced ranged from $356.5 \mathrm{~nm}-764.2 \mathrm{~nm}$ for rice straw, and $422.6 \mathrm{~nm}$ $634.0 \mathrm{~nm}$ for corn husk.
\end{abstract}

Keywords : nanocellulose, synthesis, waste

Disubmit : 3 Juli 2020; Diterima: 16 Juli 2020; Disetujui : 25 Agustus 2020

\section{PENDAHULUAN}

Padi merupakan salah satu komoditas pertanian utama Indonesia dan merupakan bahan makanan pokok bagi sebagian besar penduduk Indonesia. Total produksi padi di Indonesia pada tahun 2015 adalah sebesar 75,4 juta ton meningkat $6,42 \%$ dari tahun sebelumnya dengan produktivitas nasional sebesar 53,41 kuintal/ha. Seiring dengan produksi padi, dihasilkan pula limbah berupa jerami padi, dimana perbandingan untuk produksi padi-jerami adalah 1:1-1,5. Setiap 1 ton padi yang dipanen, dihasilkan limbah jerami padi sebanyak 1-1,5 ton. Jerami padi merupakan sumber biomassa yang mengandung 32-62\% selulosa, 18-35\% hemiselulosa, 5-25\% lignin, dan 15-19\% silika (Phanthong et al., 2018). Potensi ini membuat para peneliti di seluruh dunia termasuk di Indonesia mengarahkan fokusnya untuk memanfaatkan jerami menjadi material yang bernilai ekonomis.

Kulit jagung atau klobot jagung merupakan kulit terluar yang menutupi bulir jagung. Kulit jagung ini juga merupakan lembaran modifikasi daun yang membungkus tongkol jagung. Secara morfologi, kulit atau klobot jagung ini mempunyai permukaan yang kasar dan berwarna hijau muda 
sampai hijau tua. Jumlah rata-rata kulit jagung dalam satu tongkol adalah 12-15 lembar. Kulit jagung kering memiliki potensi yang baik sebagai sumber biomassa yang mengandung $15 \%$ lignin, 5,09\% abu, 44,08\% selulosa, dan 4,57\% bahan lainnya (Fagbemigun et al., 2014).

Serat selulosa sebagai matriks polimer telah berkembang dengan pesat dalam kurun waktu satu dekade terakhir. Hal ini disebabkan karena keunggulan-keunggulan yang dimilikinya seperti sifat mekanik yang baik, densitas yang rendah, ramah lingkungan, kelimpahan yang banyak, tidak mahal, tidak beracun, mudah didegradasi, dan termasuk kedalam sumber daya alam yang dapat diperbaharui. Serat selulosa dapat dihasilkan dari tanaman, hewan laut dan bakteri. Penggunaan tanaman hutan untuk produksi serat selulosa secara kontinyu telah secara nyata menurunkan luas dan jumlah sumber daya hutan di Indonesia. Hal ini mengakibatkan kerusakan hutan, erosi tanah, bencana banjir, tanah longsor, serta pemanasan global. Untuk mengurangi dampak negatif yang ditimbulkan oleh produksi selulosa tanaman tersebut, maka perlu ditemukan alternatif lain penghasil serat selulosa. Pemanfaatan limbah pertanian merupakan salah satu solusi untuk mendapatkan material penghasil selulosa.

Nanoselulosa secara umum dibagi menjadi 3 tipe utama yaitu selulosa nanokristal, selulosa nanofibril, dan nanoselulosa bakterial. Ketiga tipe nanoselulosa tersebut memiliki komposisi kimia yang sama namun berbeda dalam hal morfologi, ukuran partikel, kristalitas, dan properti bergantung pada sumber biomassa dan metode ektraksi yang digunakan. Selulosa nanokristal atau dikenal juga sebagai selulosa nanowhisker, biasa didapatkan dengan menggunakan hidrolisis asam dimana bagian amorf dari selulosa fiber akan dihilangkan dan menyisakan bagian yg kristalin saja. Selulosa nanorkrital berbentuk seperti batang pendek dengan diameter 2-20 nm dan panjang 100-500 nm. Selulosa nanofibril dikenal juga dengan sebutan selulosa mikrofibril, biasa diekstrak dari selulosa fibril menggunakan proses mekanis dimana bagian kristalin dan amorf masih tetap ada.

Nanoselulosa memiliki diameter 1-100 nm dan panjang 500-2000 nm. Dimensi ukuran yang dimiliki nanoselulosa dapat membuat mempunyai luas permukaan yang tinggi serta jumlah gugus hidroksil yang tinggi sehingga memudahkan jika dilakukan modifikasi permukaan. Beberapa teknik dikembangkan untuk mengekstrak nanoselulosa dari selulosa diantaranya hidrolisis asam, hidrolisis enzimatis, dan proses mekanis. Adapun penggunaan masing-masing metode ekstraksi dimungkinkan menghasilkan tipe dan properti nanoselulosa yang berbeda.

Banyak penelitian yang telah mencoba untuk mensintesis nanoselulosa dari bahan baku sumber serat lain selain kayu, misalnya limbah pertanian. Limbah pertanian yang bisa digunakan sebagai bahan sumber sintesis nanoselulosa adalah jerami gandum, tongkol jagung, daun nanas, kulit kacang kedelai, ampas tebu dan sebagainya. Pada penelitian ini dilakukan sintesis nanoselulosa dengan menggunakan limbah kulit jagung dan jerami padi dengan menggunakan variasi konsentrasi asam. Ioelovich, (2012) menggunakan metode hidrolisis dengan asam kuat, yaitu asam sulfat $\left(\mathrm{H}_{2} \mathrm{SO}_{4}\right)$. Dari berbagai variasi suhu reaksi dan rasio asam terhadap selulosa, nanoselulosa yang dihasilkan berukuran 150- $200 \times 10-20 \mathrm{~nm}$.

Brito, Pereira and Jean, (2012) menggunakan metode hidrolisis asam dengan asam kuat, yaitu asam sulfat $64 \%$ berat. Nanoselulosa yang dihasilkan berukuran 100-130 x 5- $8 \mathrm{~nm}$. Sebelum hirolisis, tahap preparasi dilakukan dengan merendam serat bambu dalam $2 \% \mathrm{w} / \mathrm{w}$ larutan $\mathrm{NaOH}$ pada $90^{\circ} \mathrm{C}$ selama empat jam dan bleaching pada $80^{\circ} \mathrm{C}$ selama tiga jam menggunakan aqueous chlorite. Selanjutnya, pulp yang telah di-bleaching dihidrolisis menggunakan asam sulfat $64 \%$ berat dengan berbagai parameter reaksi, seperti rasio asam terhadap selulosa, suhu dan waktu hidrolisis. Penelitian ini bertujuan untuk melakukan sintesis nanoselulosa dari limbah hasil pertanian dengan berbagai konsentrasi asam untuk menghasilkan selulosa dengan ukuran nano terbaik berkisar antara $1-100 \mathrm{~nm}$. 


\section{METODE PENELITIAN}

Penelitian ini dilaksanakan pada bulan April sampai September 2019 di Laboratorium Teknologi Hasil Pertanian (THP) Politeknik Negeri Lampung dan analisa dilakukan di Laboratorium Terpadu dan Sentra Inovasi Teknologi Universitas Lampung. Alat yang digunakan yaitu erlenmeyer, gelas beker, gelas ukur, hotplate, magnetic stirrer, oven, blender, ayakan, kertas saring, pipet tetes, pipet volume, mortar, sentrifius, Scanning Electron Microscope (SEM-EDX) ZEISS EVO® MA 10, dan lain-lain. Bahan yang digunakan yaitu limbah hasil pertanian (jerami padi dan kulit jagung), $\mathrm{NaOH}, \mathrm{NaOCl}$, Akuades, $\mathrm{H}_{2} \mathrm{SO}_{4}$, dan lain-lain. Penelitian ini dilakukan dengan melakukan sintesis nanoselulosa dengan tahapan melakukan isolasi selulosa dengan hidrolisis basa dan dilakukan pemutihan untuk mendapatkan serbuk selulosa. Selanjutnya dilakukan isolasi nanoselulosa dengan menggunakan asam, hingga menghasilkan nanoselulosa. Diagram alir proses isolasi selulosa dan nanoselulosa dapat dilihat pada Gambar $1(\mathrm{a}, \mathrm{b})$.
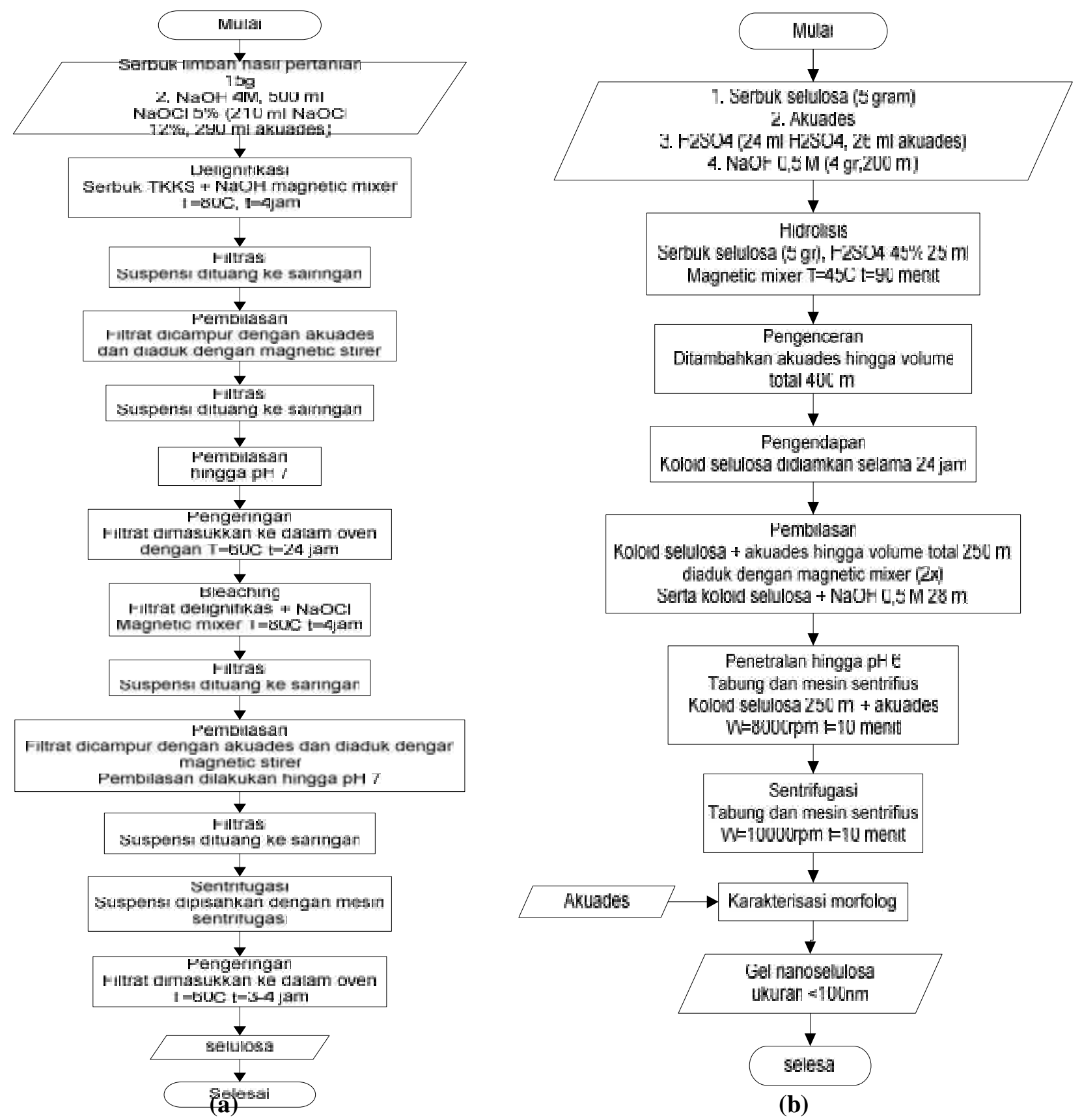

Gambar 1. (a) Diagram Alir Proses Isolasi Selulosa (b) proses pembuatan nanoselulosa 
Nanoselulosa limbah hasil pertanian (jerami padi dan kulit jagung) yang diperoleh diamati rendemen yang dihasilkan dan dilakukan pengujian morfologi dan dikarakterisasi dengan menggunakan Scanning Electron Microscopy (SEM). Pengujian SEM ini memiliki fungsi untuk mengetahui morfologi, ukuran partikel, pori serta bentuk partikel material dari nanoselulosa limbah jerami padi dan kulit jagung.

Perlakuan awal yang dilakukan sebelum sintesis nanoselulosa yaitu, limbah hasil pertanian dalam hal ini adalah kulit jagung dan jerami padi dilakukan pengeringan terlebih dahulu dibawah sinar matahari selama 1-2 hari, hingga kadar air $+12-15 \%$ untuk memaksimalkan rendemen selulosa yang didapatkan.

\section{HASIL DAN PEMBAHASAN}

Hidrolisis limbah hasil pertanian kulit jagung dan jerami padi dilakukan dengan menggunakan asam kuat $\mathrm{H} 2 \mathrm{SO} 4$ dengan konsentrasi 45\%, 55\%, dan 65\% terhadap limbah hasil pertanian kulit jagung dan jerami padi. Hasil penelitian yang didapatkan berupa serbuk kulit jagung/jerami padi, serbuk selulosa, dan nanoselulosa. Hasil peneltian dapat dilihat pada Tabel 1 dan 2. Hasil penelitian menunjukkan bahwa terjadi penurunan rendemen nanoselulosa yang dihasilkan seiring dengan meningkatnya konsentrasi larutan asam yang digunakan.

Tabel 1. Hasil perlakuan konsentrasi asam terhadap rendemen nanoselulosa kulit jagung

\begin{tabular}{lllll}
\hline Konsentrasi asam & \multicolumn{1}{c}{$\begin{array}{c}\text { Bahan baku } \\
(\mathrm{g})\end{array}$} & $\begin{array}{c}\text { Serbuk kulit } \\
\text { jagung }(\mathrm{g})\end{array}$ & $\begin{array}{c}\text { Serbuk selulosa } \\
(\mathrm{g})\end{array}$ & $\begin{array}{c}\text { Nanoselulosa } \\
(\mathrm{g})\end{array}$ \\
\hline $45 \%$ & 15 & 8,5781 & 4,4840 & 0,2002 \\
$55 \%$ & 15 & 9,6707 & 5,7006 & 0,1020 \\
$65 \%$ & 15 & 10,2598 & 1,7422 & 0,0905 \\
\hline
\end{tabular}

Tabel 2. Hasil perlakuan konsentrasi asam terhadap rendemen nanoselulosa jerami padi

\begin{tabular}{llllll}
\hline Konsentrasi asam & Bahan baku $(\mathrm{g})$ & $\begin{array}{l}\text { Serbuk } \\
\text { padi }(\mathrm{g})\end{array}$ & $\begin{array}{l}\text { jerami } \\
(\mathrm{g})\end{array}$ & $\begin{array}{l}\text { Serbuk selulosa } \\
(\mathrm{g})\end{array}$ \\
\hline $45 \%$ & 15 & 6,3490 & 2,8215 & 1,3809 \\
$55 \%$ & 15 & 7,5209 & 5,4141 & 0,2340 \\
$65 \%$ & 15 & 7,6580 & 2,0157 & 0,1003 \\
\hline
\end{tabular}

Effendi, D.B. et al., ( 2015) menyatakan Sintesis nanoselulosa dapat dilakukan dengan tiga metode yaitu metode mekanik, kimia, dan biologis. Metode kimia-mekanik menggabungkan prinsip kimia dan mekanik untuk memproduksi nanoselulosa. Sintesis nanoselulosa limbah hasil pertanian dimulai dengan melakukan isolasi selulosa dari kulit jagung dan jerami padi dengan menggunakan perlakuan basa yaitu $\mathrm{NaOH} 4 \mathrm{M}$ dan $\mathrm{NaOCl} 5 \%$ dan dilakukan pengeringan. Serbuk selulosa yang telah didapatkan selanjutnya dilakukan isolasi nanoselulosa dengan menggunakan asam kuat $\mathrm{H} 2 \mathrm{SO} 4$ dengan konsentrasi 45\%, 55\%, dan $65 \%$, hingga didapatkanlah serbuk nanoselulosa. Analisa karakteristik nanoselulosa dilakukan dengan menggunakan SEM dengan perbesaran 500 - 2000x (Julianto, et al, 2017). Hidrolisis asam biasanya dilakukan dengan menggunakan asam sulfat yang diklaim mampu mengisolasi selulosa nanokristal dengan baik serta mampu membuat nanoselulosa terdispersi sebagai sistem koloid yang stabil berkat esterifikasi gugus hidroksil oleh ion sulfat.

Hasil penelitian sintesis nanoselulosa dengan menggunakan limbah hasil pertanian didapatkanlah nanoselulosa dengan melakukan karakterisasi serbuk nanoselulosa dengan menggunakan SEM dengan perbesaran 500 - $5000 \mathrm{x}$, didapatkanlah ukuran nanoselulosa limbah jerami padi berkisar antara 356,5 nm $764,2 \mathrm{~nm}$, sedangkan untuk ukuran nanoselulosa limbah kulit jagung berkisar antara 422,6 nm - 634,0 nm. 
Hasil analisa SEM nanoselulosa limbah jerami padi dapat dilihat pada Gambar 2 dan SEM nanoselulosa kulit jagung dapat dilihat pada Gambar 3.

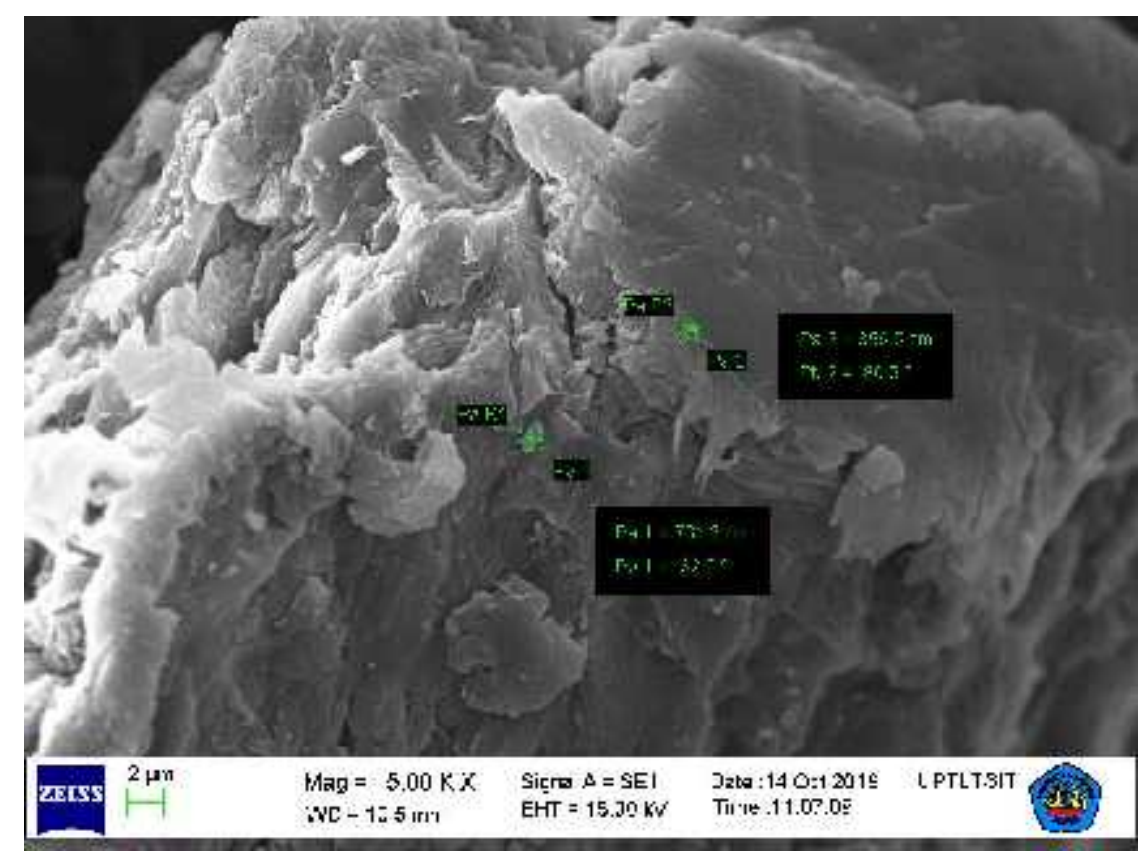

Gambar 2. Hasil analisa SEM nanoselulosa limbah jerami padi

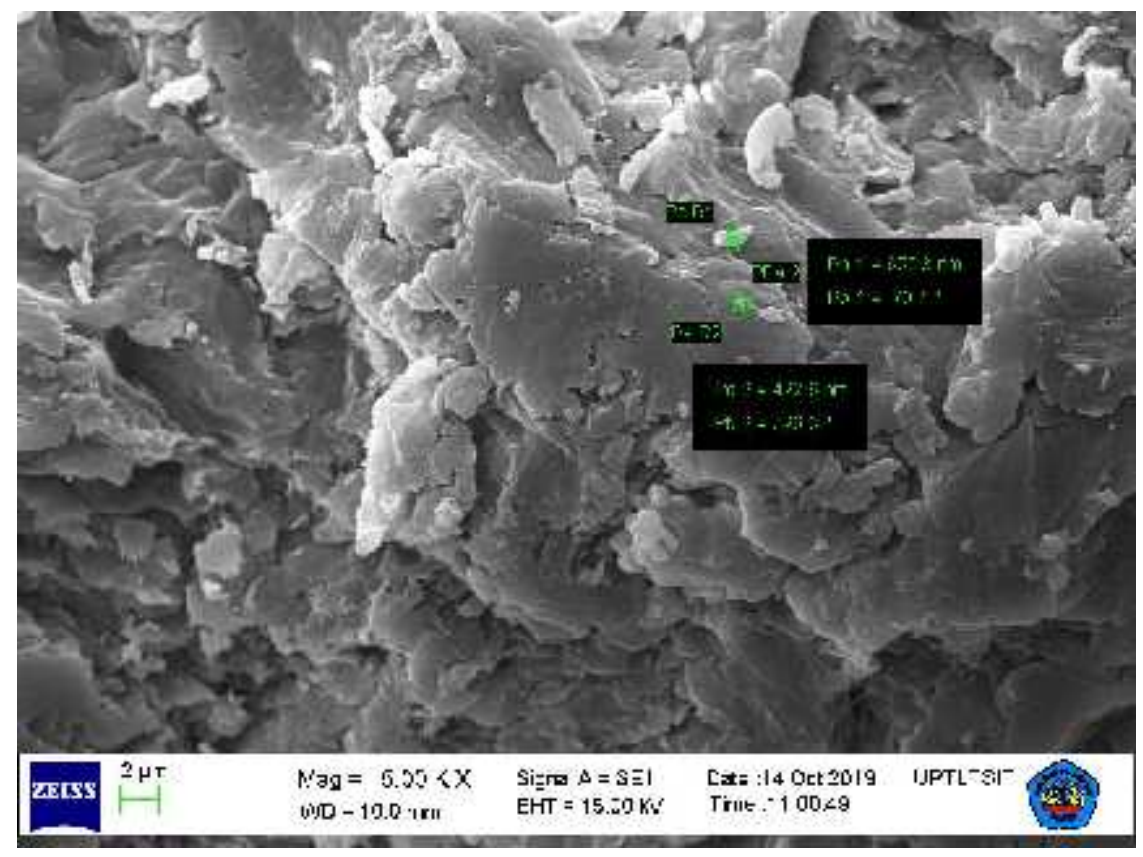

Gambar 3. Hasil analisa SEM nanoselulosa limbah kulit jagung

Zhang, et al., (2007) menggunakan metode hidrolisis asam dengan asam kuat, yaitu campuran (air deionized dengan asam klorida dan asam sulfat) pada bahan serat selulosa, nanoselulosa yang dihasilkan berukuran 60-570 nm. Asam-asam kuat yang digunakan dalam hidrolisis asam memang cocok dalam sintesis nanoselulosa. Namun, asam-asam kuat juga memiliki dampak negatif, yaitu beracun, berbahaya, dan korosif. Zhou et al., (2012) menggunakan metode hidrolisis dengan asam kuat, yaitu asam sulfat $\left(\mathrm{H}_{2} \mathrm{SO}_{4}\right) 64 \%$ berat. 
Pada suhu reaksi $45^{\circ} \mathrm{C}$ dengan pengadukan 500 rpm selama 120 menit, nanoselulosa yang dihasilkan berukuran $115 \pm 35 \mathrm{~nm}$.

Xiong et al., (2012) menggunakan metode hidrolisis asam dengan asam kuat, yaitu asam sulfat (63\% berat) sebanyak $300 \mathrm{~mL}$ pada $44^{\circ} \mathrm{C}$ dengan pengadukan dan ultrasonikasi pada $50 \mathrm{~Hz}$ selama tiga jam. Untuk menghentikan proses hidrolisis, pada larutan ditambahkan air hasil destilasi sebanyak lima kali volume campuran. Nanoselulosa yang dihasilkan berukuran 10-65 nm.

Rosa et al., (2010) menggunakan metode hidrolisis asam dengan asam sulfat pada potongan kelapa yang sebelumnya telah dilakukan tahap delignifikasi terlebih dahulu. Nanoselulosa yang dihasilkan berukuran 5-6 x 58-515 nm. Zhang, et al., (2007) menggunakan metode hidrolisis asam dengan asam kuat, yaitu campuran (air deionized dengan asam klorida dan asam sulfat) pada bahan serat selulosa. Nanoselulosa yang dihasilkan berukuran 60-570 $\mathrm{nm}$.

\section{KESIMPULAN}

Limbah hasil pertanian kulit jagung dan jerami padi merupakan bahan yang potensial untuk dijadikan nanoselulosa karena memiliki kandungan selulosa sebesar 32-76\%. Hidrolisis asam limbah hasil pertanian kulit jagung dan jerami padi menghasilkan selulosa berukuran nano yang bervariasi. Variasi konsentrasi $\mathrm{H}_{2} \mathrm{SO}_{4}$ yang digunakan yaitu $45 \%, 55 \%$, dan $65 \%$. Hasil rendemen nanoselulosa pada kulit jagung berturutturut sebesar 0,2002 gr, 0,1020 gr, dan 0,0905 gr, sedangkan pada rendemen nanoselulosa jerami padi adalah 1,3809 gr pada konsentrasi $\mathrm{H}_{2} \mathrm{SO}_{4} 45 \%, 0,2340$ gr pada konsentrasi $\mathrm{H}_{2} \mathrm{SO}_{4} 55 \%$, dan 0,1003 gr pada konsentrasi $\mathrm{H}_{2} \mathrm{SO}_{4} 65 \%$. Ukuran nanoselulosa yang didapatkan berkisar antara 356,5 nm - 764,2 nm untuk limbah jerami padi, dan 422,6 nm - 634,0 nm untuk limbah kulit jagung

\section{DAFTAR PUSTAKA}

Brito, B. S. L., Pereira, F. V and Jean, J. P. B. (2012) 'Preparation, morphology and structure of cellulose nanocrystals from bamboo fibers’, pp. 1527-1536. doi: 10.1007/s10570-012-9738-9.

Effendi, D.B. et al. (2015) 'Sintesis Nanoselulosa. Jurnal Integrasi Proses’, Jurnal Integrasi Proses, 5(2), pp. 61-74.

Fagbemigun, T. K. et al. (2014) 'Pulp and paper-making potential of corn husk', 4(April), pp. 209-212.

Ioelovich, M. (2012) 'Optimal Conditions for Isolation of Nanocrystalline Cellulose Particles.', Nanoscience and Nanotechnology, 2(2), pp. 9-13.

Julianto, H., Farid, M. and Rayida, A. (2017) 'Ekstraksi Nanoselulosa dengan Metode Hidrolisis Asam sebagai Penguat Komposit Absorpsi Suara', Jurnal Teknik ITS, 6(2), pp. 242-245.

Phanthong, P. et al. (2018) 'Nanocellulose: Extraction and application', Carbon Resources Conversion. KeAi Communications Co., Ltd, 1(1), pp. 32-43. doi: 10.1016/j.crcon.2018.05.004.

Rosa, M. F. et al. (2010) 'Cellulose nanowhiskers from coconut husk fibers: Effect of preparation conditions on their thermal and morphological behavior', Carbohydrate Polymers, 81, pp. 83-92.

Xiong, R. et al. (2012) 'Comparing microcrystalline with spherical nanocrystalline cellulose from waste cotton fabrics', Cellulose. 2012(19), pp. 1189-1198.

Zhang, J. et al. (2007) 'Facile synthesis of spherical cellulose nanoparticles', Carbohydrate Polymers, 2007(69), pp. 607-611.

Zhou, Y. M. et al. (2012) 'Effect of nanocellulose isolation techniques on the formation of reinforced poly (vinyl alcohol ) nanocomposite films', 6(10), pp. 794-804. doi: 10.3144/expresspolymlett.2012.85. 